\title{
COHORT STUDY OF MICHIGAN RESIDENTS EXPOSED TO POLYBROMINATED BIPHENYLS: EPIDEMIOLOGIC AND IMMUNOLOGIC FINDINGS
}

\author{
Philip J. Landrigan, * Kenneth R. Wilcox, Jr., $\dagger$ Joseph Silva, Jr., \\ Harold E. B. Humphrey, $†$ Carol Kauffman, $\$$ \\ and Clark W. Heath, Jr.* \\ * Center for Disease Control \\ Atlanta, Georgia 30333 \\ † Michigan Department of Public Health \\ Lansing. Michigan 48933 \\ $\ddagger$ University of Michigan Medical Center \\ Ann Arbor, Michigan 48104
}

\section{INTRODUCTION}

The polybrominated biphenyls (PBB) are a group of halogenated aromatic hydrocarbon compounds employed until recently as flame retardants in the plastics industry. 'PBB have low acute toxicity, ${ }^{2}$ but are fat-soluble, biologically persistent, ${ }^{3}$ and capable of causing chronic injury to the liver, ${ }^{4}$ kidneys, ${ }^{5}$ skin, ${ }^{5}$ and lymphatic tissue. ${ }^{6}$ In addition, PBB have been found in chronic rat feeding studies to induce neoplastic liver nodules. ${ }^{4}$

In 1973, several hundred pounds of PBB were introduced into cattle feed as the result of a shipping accident in Michigan. ${ }^{7}$ Thousands of dairy animals ${ }^{8}$ died or were destroyed, and widespread human exposure resulted from contact with contaminated feed and from consumption of PBB in dairy foods. While human exposure was most intense on quarantined farms, ${ }^{9}$ and in chemical workers, ${ }^{10}$ low-level exposure was widespread throughout the state, and in October, 1976, a survey of randomly selected samples of human breast milk showed that $51(96 \%)$ of 53 samples from the lower peninsula of Michigan contained detectable levels of PBB."

To determine the effects of PBB exposure on human health, the Michigan Department of Public Health (MDPH), the Center for Disease Control (CDC), the National Institutes of Health (NCI and NIEHS), the Food and Drug Administration (FDA), and the Environmental Protection Agency (EPA) have established a cohort of persons with varying levels of PBB exposure. The members of this cohort have been examined systematically to determine whether or not they have experienced an increased incidence of acute or subacute iliness, of biochemical aberrations, or of alterations in the outcome of pregnancy in relation to their PBB exposure. In addition, the health status of the cohort is to be followed prospectively over the next several decades to determine whether they will experience an increased incidence of chronic disease, particularly of cancer. In this report, we shall summarize the epidemiologic and clinical data collected on the Michigan cohort in the first 4 years since the onset of PBB exposure. In addition, we shall present the results of an immunologic study conducted in 1977 to evaluate peripheral lymphocyte function in the most heavily exposed subset of the cohort. 


\section{METHODS}

\section{Selection of Participants}

Four categories of Michigan residents were invited by mail and by interview to participate in this prospective cohort study:

\section{Farm Residents on Quarantined Farms}

Invited to join this group were the 2,248 persons who were members of families residing on quarantined farms at the time of those farms' quarantine for PBB contamination; included here were 110 residents of quarantined farms who had participated in a 1974 MDPH pilot study of PBB exposure.' Quarantine was established when any single specimen of meat, eggs, or milk from a farm exceeded quarantine action limits; the number of specimens submitted for PBB testing varied from farm to farm. In May, 1974, the maximum allowable limit for PBB in milk or meat fat was set at 1.0 parts per million (ppm), and in eggs at $0.1 \mathrm{ppm}$, and 183 farms were quarantined. In November, 1974, these quarantine action limits were decreased

TABLE 1

Survey Participation Rates by Enrollment Group (Michigan PBB Study, 1976-77)

\begin{tabular}{lccc}
\hline \multicolumn{1}{c}{ Group } & Invited (No.) & Enrolled (No.) & $(\%)$ \\
\hline 1. Quarantined farm residents & 2248 & 2148 & 95.6 \\
$\begin{array}{l}\text { 2. Farm product recipients } \\
\text { 3. Chemical workers }\end{array}$ & 1495 & 1421 & 95.1 \\
$\begin{array}{c}\text { (and families) } \\
\text { 4. Pilot study control } \\
\text { participants }\end{array}$ & 322 & 251 & 78.0 \\
\hline \hline
\end{tabular}

to $0.3 \mathrm{ppm}$ for milk and meat fat, and to $0.05 \mathrm{ppm}$ for eggs, and another 229 farms were quarantined. Additional farms have subsequently been placed under quarantine. The survey participation rate in Group 1 was $95.6 \%$ (TABLE 1).

\section{Farm Product Recipients}

Invited into this group were 1,495 persons who had not themselves resided on quarantined farms, but who had received meat, eggs, or dairy products directly from quarantined premises in 1973 or 1974 . The participation rate in Group 2 was $95.1 \%$ (TABLE 1).

\section{Chemical Workers}

This group includes workers, who had been exposed occupationally to PBB in a chemical manufacturing plant in Michigan, as well as the members of these workers' 
families. The total number invited was 322 ; the participation rate was $78.0 \%$ (TABLE 1).

\section{Pilot Study Participants}

Invited to join this group were 60 persons who had been identified in the MDPH pilot study ${ }^{9}$ as being resident on farms with low-level PBB contamination; they had served as a control group in the pilot study. The participation rate in this group was 95.0\% (TABLE 1).

Finally, a small number of additional persons were enrolled into the cohort who were not originally invited to participate:

(1) 331 self-referred persons who had either resided on farms identified as being contaminated by PBB in levels below quarantine limits or who had eaten food produced on such farms (Group 5); and

(2) 337 self-referred volunteers who had no direct connection with contaminated farm premises (Group 6).

\section{Field Studies}

All persons enrolled in the study were visited in their homes over a 12-month period between September, 1976 and August, 1977, by trained interviewers from MDPH. Repeated visits (up to 4 per household) and repeated mailings were made in an attempt to reach families who could not initially be contacted, or who refused in the first instance to participate in the cohort study. After informed consent had been obtained for each person, a questionnaire was administered which sought data on potential sources of PBB exposure, as well as on the occurrence since 1973 of 17 symptoms and conditions considered possibly related to PBB contact. This symptom list was developed from anecdotal data on the possible human toxicity of $\mathrm{PBB}^{8}$ as well as from published information ${ }^{12}$ on the human toxicity of the polychlorinated biphenyls (PCB). Symptoms and conditions sought were weight loss, fatigue, headaches, skin rash, changes in skin pigmentation, changes in the nails, heart disease, gastrointestinal complaints (nausea, vomiting, diarrhea, or abdominal pain), liver disease, Reye's syndrome, diabetes mellitus, thyroid disease, peripheral neuropathy, convulsions, joint disease, benign tumors, and cancer. Data were obtained also on tobacco and alcohol consumption. Detailed information, including birth weight data and data on any congenital malformations, was sought on the outcome of all pregnancies since 1963 .

\section{Toxicologic Laboratory Studies}

A venous blood sample for PBB analysis was requested of each study participant, and 3,639 were obtained. Samples were analyzed for PBB concentration at MDPH using gas chromatography with electron capture detection; the limit of detection for PBB was 1 part per billion (ppb).

Quality control on PBB analysis was conducted jointly by MDPH and the Toxicology Branch. Clinical Chemistry Division, Bureau of Laboratories, CDC. In addition to internal quality control at MDPH, which consisted of repeated analyses of quality control specimen pools, external surveillance was provided by (a) repeat analysis at CDC of $13 \%$ of samples, and (b) blind insertion by CDC of quality 
evaluation specimens into the regular system of specimen collection. For 466 serum samples analyzed in duplicate at MDPH and CDC, mean PBB values were 16.9 and $16.2 \mathrm{ppb}$ respectively; the coefficient of correlation between paired results was 0.9982 .

\section{Immunologic Studies}

To evaluate peripheral lymphocyte function in the members of the cohort identified previously as having highest serum PBB values, an immunologic investigation was undertaken by MDPH and CDC in collaboration with the University of Michigan (UM) in October, 1977.

Invited to participate were all 41 cohort members shown previously to have serum PBB values $\geq 300 \mathrm{ppb} ; 34$ of these $41(83 \%)$ agreed to participate. Invited as a comparison group were all 7 persons shown to have a serum PBB concentration less than $1 \mathrm{ppb}$, as well as a random sample of 59 of the 915 enrollees with serum values of $1-9 \mathrm{ppb} ; 56(85 \%)$ of these 66 persons agreed to participate.

Fasting early morning venous blood specimens, taken from 8-10 persons per day, were collected in heparinized vacuum tubes over a 3-week period in participants' homes and at nearby field stations. Members of both exposure groups were included each day. Samples were coded in the field and then transported at ambient temperature by automobile to the UM laboratory where test procedures were begun 3-5 hours after venipuncture. To examine for any possible decrement in lymphocyte function during transport, blood samples were obtained in the field from 1-3 MDPH staff members each day (total, 9 persons, 33 samples) from whom blood samples had previously been taken in the UM laboratories and tested immediately.

Mononuclear cells were obtained by centrifugation through a ficoll-isopaque gradient. ${ }^{13}$ The mononuclear cell layer was removed and washed twice in Hanks' balanced salt solution (HBSS). Cells to be used for T and B lymphocyte enumeration were resuspended in HBSS, counted, and diluted to a final concentration of $4 \times 10^{6}$ mononuclear cells $/ \mathrm{ml}$. Cells to be used for lymphocyte transformation were resuspended in RPMI-1640 (GIBCO, Grand Island, N.Y.), and counted and diluted to a concentration of $10 \times 10^{6}$ cells $/ \mathrm{ml}$. These procedures gave greater than $99 \%$ cell viability as determined by exclusion of $1 \%$ trypan blue dye.

B cells were enumerated by detecting complement receptors by means of complement-coated zymosan particles according to the methods of Mendes et al. ${ }^{14}$ Two-hundred lymphocytes were counted in duplicate specimens using a phase microscope; cells that had three or more zymosan particles attached were recorded as $B$ cell rosettes.

T lymphocytes were enumerated by determining the number of cells that formed rosettes spontaneously with sheep erythrocytes according to the method of Jondal et $a l^{15}$ Two-hundred lymphocytes were counted in duplicate specimens using a phase microscope. Cells that had three or more erythrocytes attached were recorded as $T$ cell rosettes.

Peripheral blood lymphocytes were studied for transformation to three mitogens, phytohemagglutinin (PHA), concanavalin A (Con A), and pokeweed mitogen (PWM) in wells of flat-bottomed microtiter plates. Each mitogen was run in quadruplicate wells that contained $10^{5}$ lymphocytes/well in a total volume of $0.2 \mathrm{ml}$ RPMI-1640 with $20 \%$ autologous plasma.

Microtiter plates were placed in a $5 \% \mathrm{CO}_{2}$ humidified incubator at $37^{\circ} \mathrm{C}$. After incubation for 96 hours cells were pulsed with 1 microcurie $(\mu \mathrm{Ci})$ of ${ }^{3} \mathrm{H}$-thymidine and 
TABLE 2

Mean age and Percentage male and Female by Enrollment Group (Michigan PBB Study, 1976-77)

\begin{tabular}{lccc}
\hline \multicolumn{1}{c}{ Group } & Mean Age (yrs) & $\begin{array}{c}\text { Percentage } \\
\text { Male }\end{array}$ & $\begin{array}{c}\text { Percentage } \\
\text { Female }\end{array}$ \\
\hline 1. Quarantined farm residents & 28.0 & 52.6 & 47.4 \\
2. Farm product recipients & 28.3 & 48.4 & 51.6 \\
3. Chemical workers & & & \\
$\quad$ (and families) & 22.6 & 51.6 & 48.4 \\
4. Pilot study control participants & 33.7 & 50.0 & 50.0 \\
5. Low-Level PBB farm residents & 27.9 & 53.1 & 46.9 \\
6. Volunteers & 29.4 & 50.8 & 49.2 \\
\hline \hline
\end{tabular}

harvested 6 hours later with an Otto-Hillier cell harvester. Cells were then washed with saline, dried, resuspended in scintillation fluid and counted. Data were expressed as mean counts per minute (cpm) per $10^{5}$ lymphocytes.

\section{EPIDEMIOLOGIC RESULTS}

Members of the Michigan cohort ranged in age from 1 to 89 years (median, 24 years) at the time of enrollment; 2,317 were male and 2,220 female ( 8 of unspecified sex). Age and sex distributions were approximately comparable in the 6 groups (TABLE 2).

Analysis of data on the prevalence of symptoms showed that fatigue, headaches, paresthesias, and joint problems were the conditions most frequently reported. For nearly all conditions the volunteer group (Group 6) had the highest prevalence, followed closely by the group who had resided on farms with low-level PBB contamination (Group 5) (TABLE 3).

Data on serum PBB levels showed a range of values from 0-1900 parts per billion (ppb); 106 values were greater than $100 \mathrm{ppb}$. Examination of results by age-group showed that children aged 10 years or less tended to have the highest serum PBB concentrations. Above age 10, there was no significant gradient by age $(\mathrm{F}=1.81, \mathrm{p}=$ $0.11)$. Males had significantly higher values than females $\left(\chi^{2}=256.5 ; p<10^{-10}\right)$.

TABLE 3

Prevalence Rates $(\%)$ for Selected Symptoms by Enrollment Group (Michigan PBB Study, 1976-77)

\begin{tabular}{|c|c|c|c|c|c|c|}
\hline \multirow{2}{*}{$\begin{array}{l}\text { Symptoms and } \\
\text { Conditions }\end{array}$} & \multicolumn{6}{|c|}{ Group } \\
\hline & 1 & 2 & 3 & 4 & 5 & 6 \\
\hline Fatigue & 36.4 & 32.4 & 22.0 & 15.8 & 41.4 & 54.4 \\
\hline Rashes & 8.1 & 7.5 & 6.4 & 1.8 & 14.5 & 3.1 \\
\hline Joint pains & 25.1 & 26.4 & 18.9 & 11.1 & 32.0 & 39.9 \\
\hline Hepatitis & 1.5 & 1.8 & 1.6 & 0.0 & 3.3 & 3.6 \\
\hline Diabetes mellitus & 1.9 & 2.2 & 2.4 & 1.8 & 2.7 & 2.4 \\
\hline Benign tumors & 4.2 & 5.4 & 5.8 & 1.8 & 5.5 & 9.8 \\
\hline Cancer-all sites & 0.4 & 0.5 & 0.4 & 0.0 & 0.6 & 0.6 \\
\hline $\begin{array}{l}\text { Number of } \\
\text { subjects }\end{array}$ & 2428 & 1421 & 251 & 57 & 331 & 337 \\
\hline
\end{tabular}


Serum PBB levels showed a strong tendency to cluster by families (intra-class coefficient of correlation $=0.85$ ).

Examination of serum PBB levels by enrollment group showed that highest values were found in the chemical workers and in the members of their families (TABLE 4) followed by the residents on quarantined farms (Group 1). In the chemical worker group, the workers themselves had a serum PBB level of $108.7 \mathrm{ppb}$ (range, 0-1,240 $\mathrm{ppb}$ ), significantly higher than that in members of their families. Volunteers (Group 6) had the lowest serum PBB levels.

Paired serum samples, one collected in 1974 and the other in 1977, were available for 148 members of the cohort. These data indicate that serum levels were generally stable over the 3-year period. The mean change in serum ppb value was $-16 \mathrm{ppb}$, and the coefficient of correlation ( $r$ ) between the 2 sets of values was 0.96 .

Simultaneous paired specimens of blood and adipose tissue were obtained on 221 Michigan residents, 19 of whom were members of the cohort. A high coefficient of correlation ( $r$ ) was seen between these 2 sets of values $(0.951)$, and in the 132

TABLE 4

Serum PBB Levels* by Enrollment Group

(Michigan PBB StUdy, 1976-77)

\begin{tabular}{|c|c|c|c|c|}
\hline \multirow[b]{2}{*}{ Group } & \multicolumn{4}{|c|}{ Serum PBB } \\
\hline & Number & Range & Mean & Median \\
\hline 1. Quarantined farm residents & 1750 & $0-1900$ & 26.9 & 4.0 \\
\hline 2. Farm product recipients & 1114 & $0-659$ & 17.1 & 3.0 \\
\hline 3. Chemical workers & & & & \\
\hline (and families) & 216 & $0-1240$ & 43.0 & 4.5 \\
\hline 4. Pilot study control & & & & \\
\hline participants & 44 & $1-13$ & 3.5 & 2.0 \\
\hline 5. Low-level PBB farm residents & 242 & $0-24$ & 3.5 & 2.0 \\
\hline 6. Volunteers & 273 & $0-111$ & 3.2 & 1.0 \\
\hline Total & $\overline{3639}$ & $0-1900$ & 21.2 & $\overline{3.0}$ \\
\hline
\end{tabular}

*PBB levels in parts per billion (ppb).

instances where both values were above detection limits the ratio of adipose to serum PBB concentrations was 362.8:1.0 (FIGURE 1).

An evaluation of dose-response relationships was undertaken by dividing the cohort into seven segments on the basis of serum PBB levels. No positive associations were found between serum concentrations of $\mathrm{PBB}$ and reported symptom frequencies (TABLE 5). Symptom-prevalence rates (excluding volunteers) were slightly higher in persons with no detectable PBB in serum than in those with measurable quantities. Relationships between symptom prevalence rates and serum PBB level were also examined within each enrollment group, and no positive trends were found; in all groups, including chemical workers and quarantined farm residents, highest prevalence rates occurred in persons with lowest serum PBB levels.

Since 1973, 65 children have been born to women in Michigan with potential exposure to PBB (TABLE 6). Serum PBB concentrations in the 52 women examined at the time of delivery ranged from not detectable $(<1 \mathrm{ppb})$ to $1150 \mathrm{ppb}$ (mean, 26.2 $\mathrm{ppb}$ ). Cord serum PBB levels at birth in 58 infants ranged from not detectable to 104 $\mathrm{ppb}$ (mean $3.2 \mathrm{ppb}$ ). The mean ratio of maternal/cord serum PBB values for the 13 maternal-infant pairs where both had detectable values was 7.04:1.0 (range, 1.5- 
10.3). Breast milk samples were obtained from 32 women, and $P B B$ values (fat basis) ranged from 32 to $93,000 \mathrm{ppb}$ (mean $3614 \mathrm{ppb}$ ). The mean ratio of serum to breast milk PBB values in the 21 women where both concentrations were detectable was 122.0:1.0 (range, 62.6-256.7).

\section{IMMUNOLOGIC RESULTS}

Total leucocyte counts did not differ significantly among the high PBB, low PBB, and MDPH staff groups. The mean percentage of circulating lymphocytes was significantly elevated in the high PBB exposure group as compared to the low $(p<$ 0.0001 ). However, this increase was found only in children less than 12 years of age who made up a greater proportion of the high than of the low exposure group.

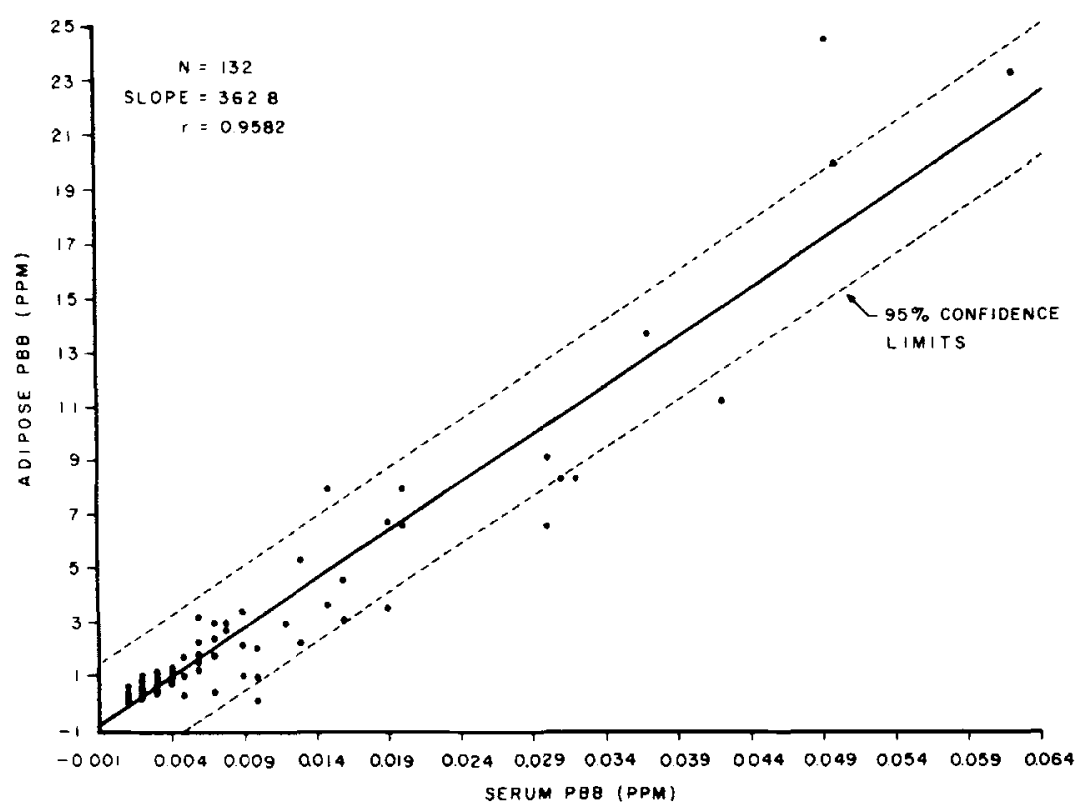

FigURE 1. Correlation between simultaneous paired serum and adipose PBB levels. Michigan PBB Study, 1976-1977.

The high exposure group had no depressions in absolute numbers of $T$ or $B$ lymphocytes, or in responses to any of the 3 mitogens as compared to the group with low PBB exposure (TABLE 7). However, 15\% of persons from the 2 exposure groups were found to have 2 or more abnormalities in measures of in vitro lymphocyte function.

Significant differences were found (TABLE 7) between results obtained in the field on MDPH staff and results obtained on these same individuals in the nontransported samples taken at the UM laboratory; this discrepancy suggests the possible existence of a "transportation effect." 
TABLE 5

Percentage Incidence of Reported Symptoms and Conditions* SinCE 1973 By SERUM PBB† LeVel

(Michigan, PBB Study, 1976-77

\begin{tabular}{|c|c|c|c|c|c|c|c|c|}
\hline $\begin{array}{c}\text { Symptoms and } \\
\text { Conditions }\end{array}$ & $\mathbf{0}$ & 1 & $2-3$ & 4-9 & $10-19$ & $20-99$ & $100+$ & Mean \\
\hline Fatigue & 46.5 & 40.1 & 40.7 & 38.1 & 37.8 & 28.7 & 27.4 & 38.3 \\
\hline Rashes & 9.0 & 8.5 & 8.4 & 7.2 & 8.3 & 6.3 & 4.1 & 7.8 \\
\hline Joint pains & 42.9 & 32.7 & 29.8 & 26.4 & 28.4 & 21.6 & 17.1 & 28.6 \\
\hline Hepatitis & 4.5 & 1.4 & 1.8 & 1.4 & 1.3 & 0.0 & 0.0 & 1.4 \\
\hline \multicolumn{9}{|l|}{ Diabetes } \\
\hline mellitus & 4.7 & 2.9 & 2.4 & 1.8 & 1.9 & 3.3 & 0.0 & 2.4 \\
\hline Benign tumors & 2.7 & 7.5 & 5.6 & 4.3 & 5.3 & 3.8 & 2.6 & 5.3 \\
\hline \multicolumn{9}{|l|}{ Cancer-all } \\
\hline sites & 0.0 & 0.9 & 0.5 & 0.5 & 1.0 & 0.4 & 1.8 & 0.6 \\
\hline $\begin{array}{l}\text { Number of } \\
\text { subjects* }\end{array}$ & 89 & 716 & 941 & 892 & 316 & 276 & 126 & 3,356 \\
\hline
\end{tabular}

*Excludes volunteer subjects.

†PBB concentrations in parts per billion (ppb).

\section{DISCUSSION}

The finding in this study of elevated serum PBB levels in families from quarantined farms and in Michigan chemical workers confirms earlier reports of increased PBB absorption in these groups. ${ }^{9-11}$ Although a number of exposed individuals reported symptoms, as has been the case in previous studies, ${ }^{16.17}$ it was noteworthy that symptom prevalence rates bore no relationship to serum PBB levels.

TABLE 6

PbB Concentrations* in Maternal Serum, Cord Serum, AND BREAST MILK ${ }^{\dagger}$

(MICHIGAN PBB STUDY, 1976-77)

\begin{tabular}{|c|c|c|c|c|c|}
\hline \multirow[b]{2}{*}{ Specimen } & \multirow[b]{2}{*}{ Number } & \multicolumn{4}{|c|}{ PBB Concentrations } \\
\hline & & Range & Mean & Median & $\begin{array}{c}\text { Average Ratio } \\
\text { to Maternal } \\
\text { Serum } \\
\text { (and Range) }\end{array}$ \\
\hline $\begin{array}{l}\text { Maternal } \\
\text { serum }\end{array}$ & 52 & $0-1,150$ & 26.2 & 2.5 & - \\
\hline $\begin{array}{l}\text { Cord } \\
\text { serum }\end{array}$ & 58 & $0-104$ & 3.2 & 1.0 & $\begin{array}{l}7.04 \\
(1.5-10.3)\end{array}$ \\
\hline $\begin{array}{r}\text { Breast } \\
\text { milk }\end{array}$ & 32 & $32-93,000$ & 3614 & 225 & $\begin{array}{l}122.0 \\
(62.2-256.7)\end{array}$ \\
\hline
\end{tabular}

*PBB concentrations in parts per billion (ppb).

$\dagger$ Breast milk PBB values expressed on fat basis. 


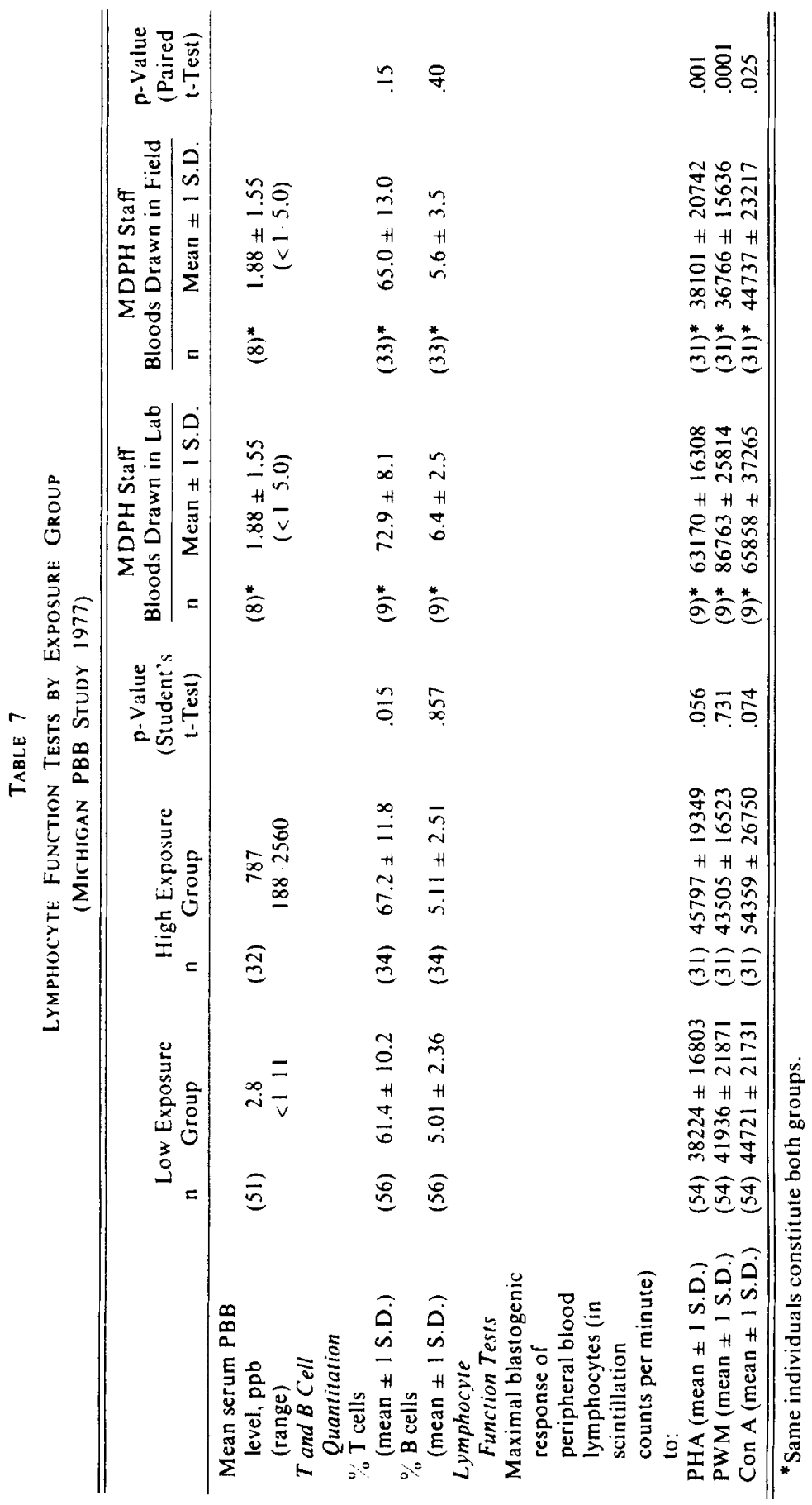


Symptom frequency was much more closely related to mode of entry into the cohort, with highest frequencies occurring in volunteers (Group 6) and in persons from farms that were contaminated by PBB at levels insufficient to result in quarantine (Group 5). These observations suggest that factors other than PBB absorption may have been responsible for the production of symptoms and that selection factors may have played an important role. Also, however, it may be necessary to examine samples of the commercial PBB mixture dispersed in Michigan to determine whether it contained other toxins in addition to $\mathrm{PBB}$, possibly in concentrations not correlated directly with PBB levels.

The failure of this investigation and of a previous immunologic study ${ }^{18}$ to demonstrate dose-related depression of lymphocyte function in persons exposed to PBB suggests that there may be no causal relation between the two. If, however, an association does exist, our failure to detect it could have resulted from any of several possibilities. One is that the methods used in this study were insufficiently sensitive. Another is that the 3-5 hours' transportation time required here may have depressed cell function in both of our groups to a point where intergroup differences were no longer evident. A third is that persons in both study groups (as well as MDPH field staff) may have had exposure to PBB at concentrations above a threshold level for lymphocyte depression; hence all may have been equally depressed. A final possibility is that recovery of immunologic function may have occurred in the exposed population in Michigan in the 8 months which elapsed between this and the previous, more strongly positive study. ${ }^{18}$ Further investigation will be required to distinguish among these possibilities, and to explore the clinical significance of the immunologic abnormalities observed in members of the two exposure groups.

PBB is a highly lipophilic compound and extremely persistent in the human body. Persons exposed to PBB may be at potentially increased risk of developing delayed reactions, particularly cancer, since PBB fed to rats, has produced neoplastic liver nodules. ${ }^{4}$ Because of the potential for delayed disease, MDPH and the federal agencies plan to continue to follow the Michigan cohort for at least another 10-15 years through repeated contact with the exposed persons and their family physicians. Also, within the next year, a cohort of approximately 2000 lowa farm residents without known exposure to PBB is to be recruited and interviewed using procedures identical to those used in Michigan; this group will be followed prospectively as a comparison cohort.

\section{SUMMARY}

Polybrominated biphenyls (PBB) were dispersed widely in Michigan by a 1973 shipping accident in which PBB was introduced into cattle feed. Human exposure resulted principally from ingestion of contaminated dairy food products. To determine whether PBB exposure has or will cause acute or chronic illness, a prospective cohort study of 4545 persons has been undertaken. Three exposure groups were sought: all persons living on PBB-quarantined farms; persons who had received food directly from such farms; workers (and their families) engaged in PBB manufacture. Enrollment rates were $95.6,95.1$ and $78.0 \%$. Also enrolled were 725 persons with low-level PBB exposure. All were queried concerning 17 symptoms and conditions related possibly to PBB. Venous blood was drawn on 3639 and analyzed for PBB by gas chromatography. Mean serum PBB levels were $26.9 \mathrm{ppb}$ in quarantined farm families, 17.1 in recipients, $43.0 \mathrm{ppb}$ in workers, and $3.4 \mathrm{ppb}$ in the low exposure groups. No associations were found between serum PBB levels and symptom prevalence rates. To evaluate peripheral lymphocyte function, $\mathrm{T}$ and $\mathbf{B}$ cell quantitation and in vitro 
responses to 3 nonspecific mitogens were studied in 34 persons with highest PBB levels (mean, $787 \mathrm{ppb}$ ), and in 56 with low values (mean, $2.8 \mathrm{ppb}$ ). No statistically significant differences in lymphocyte number or function were noted.

\section{REFERENCES}

1. Sanders, H. J. 1978. Flame retardants--special report. Chem. Eng. News, April 24, 1978: 22-36.

2. Aftosmis, J. G., R. Culik, K. P. LeE, H. Sherman \& R. S. Waritz. 1972. Toxicology of brominated biphenyls. I. Oral toxicity and embryotoxicity (Abstr.) Toxicol. Appl. Pharmacacol. 22: 316.

3. Matthews, H. B., S. Kato, N. M. Morales \& D. B. Tuey. 1977. Distribution and excretion of $2,4,5,2,4,5$,-hexabromobiphenyl, the major component of Firemaster BP-6. J. Toxicol Environ. Health 3: 599-605.

4. Kimbrough, R. D., V. W. BurSe \& J. A. LiddeE. 1977. Toxicity of polybrominated biphenyl. Letter. Lancet 2: 602-603.

5. MoOrhead, P. D. L. B. Willetr \& F. L. Schanbacher. 1978. Effects of PBB on cattle. 11. Gross pathology and histopathology. Environ. Health Perspect. 23: 111-118.

6. Luster, M., R. E. FAith \& J. A. MOORE. 1978. Effects of polybrominated biphenyls (PBB) on immune response. Environ. Health Perspect. 23: 227-232.

7. CARTER, L. J. 1976. Michigan's PBB incident: chemical mix-up leads to disaster. Science 192: $240-243$.

8. JACKSON, T. F. \& F. L. HALBERT. 1974. A toxic syndrome associated with the feeding of polybrominated biphenyl- contaminated protein concentrate to dairy cattle. J. Am. Vet. Med. Assoc. 165: 437-439.

9. Humphrey, H. E. B. \& N. S. Hayner. 1975. Polybrominated biphenyls: an agricultural incident and its consequences, an epidemiological investigation of human exposure. Presented at the Ninth Annual Conference on Trace Substances in Environmental Health, Columbia, Missouri, June, 1975.

10. ANDERSON, H. A., M.S. Wolff, A. Fischbein \& I. J. Selikoff. 1978. Investigation of the health status of Michigan Chemical Corporation employees. Environ. Health Perspect. 23: $187-192$.

11. Brilliant, L. B., G. Van amburg, J. Isbister, H. Humphrey, K. Wilcox, J. Eyster, A. W. BlOOMER \& H. Price. 1978. Breast milk monitoring to measure Michigan's contamination with polybrominated biphenyls. Lancet 2: 643-646.

12. Kuratsune, M., T. Yoshimura, J. Matsuzaka \& A. Yamaguchi. 1972. Epidemiologic study on Yusho, a poisoning caused by ingestion of rice oil contaminated with a commercial brand of polychlorinated biphenyls. Environ. Health Perspect. April, 1972: 119-128.

13. BoYUM, A. 1968. Isolation of mononuclear cells and granulocytes from human blood. Scand. J. Clin. Lab. Inves. 20: 77-89.

14. MEndes, N. F., S. S. MIKI \& Z. F. Peixinho. 1974. Combined detection of human T and B lymphocytes by rosette formation with sheep erythrocytes and zymosan-C 3 complexes. J. Immunol 113: 531-536.

15. JONDAL, M., G. Holm \& H. Wigzell. 1972. Surface markers on human $T$ and $B$ lymphocytes. I. A large population of lymphocytes forming non-immune rosettes with sheep red blood cells. J. Exp. Med. 136: 207-215.

16. Anderson, H. A., R. Lilis, I. J. Selikoff, K. D. Rosenman, J. A. Valciukas \& S. FREEDMAN. 1978. Unanticipated prevalence of symptoms among dairy earners in Michigan and $W^{\prime}$ isconsin. Environ. Health Perspect. 23: 217-226.

17. MeESTER, W. D. \& D. J. MCCOY. 1977. Human toxicology of polybrominated biphenyls. Clin. Toxicol. 10: 474

18. Bekesi, J. G., J. F. Holland, H. A. Anderson, A. S. Fischbein, W. Rom, M. S. WolfF \& I. J. Selikoff. 1978. Lymphocyte function of Michigan dairy farmers exposed to polybromianted biphenyls. Science 199: 1207-1209. 